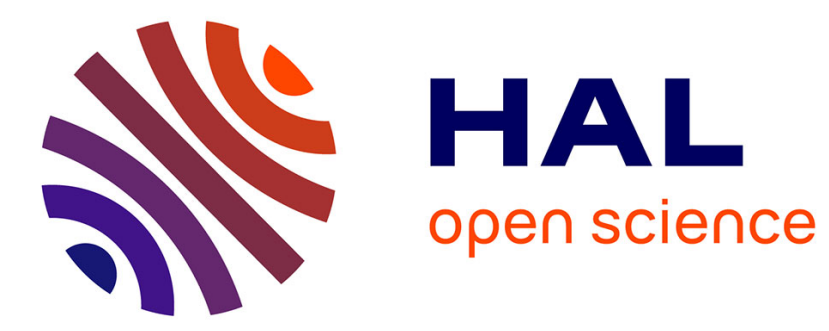

\title{
Book Review: Images of Idiocy: The Idiot Figure in Modern Fiction and Film
}

Mark Jackson

\section{To cite this version:}

Mark Jackson. Book Review: Images of Idiocy: The Idiot Figure in Modern Fiction and Film. History of Psychiatry, 2005, 16 (1), pp.133-135. 10.1177/0957154X0501600110 . hal-00570808

\section{HAL Id: hal-00570808 \\ https://hal.science/hal-00570808}

Submitted on 1 Mar 2011

HAL is a multi-disciplinary open access archive for the deposit and dissemination of scientific research documents, whether they are published or not. The documents may come from teaching and research institutions in France or abroad, or from public or private research centers.
L'archive ouverte pluridisciplinaire HAL, est destinée au dépôt et à la diffusion de documents scientifiques de niveau recherche, publiés ou non, émanant des établissements d'enseignement et de recherche français ou étrangers, des laboratoires publics ou privés. 
this reviewer), while at the same time objectively analysing its deficiencies at different stages of its development. Although the story of the institution largely follows the now-familiar pattern, this in no way detracts from its historical value. On the contrary, it is only through the assembly of such particular histories that a true picture of the birth, growth and death of the asylum can be assembled.

LEONARD D. SMITH

Centre for the History of Medicine

University of Birmingham

Martin Halliwell. Images of Idiocy: The Idiot Figure in Modern Fiction and Film. Aldershot: Ashgate, 2004. Pp. $x+$ 270. ISBN 0-7546-0265-6. £47.50.

In recent years, historical interest in idiocy has been seeping surreptitiously through the veins of Anglo-American historians of medicine. Since the early 1990s in particular, a flowing stream of doctoral dissertations, journal articles, edited volumes and monographs has been effectively charting shifting medical and educational models of intellectual disability, the establishment of novel institutional provisions, changing legislative responses to the perceived social and economic problems posed by those nowadays referred to as people with learning difficulties, and the emergence of increasingly vocal agitation for greater receptivity to the stories and arguments of self-advocates. In some instances, people with learning difficulties have themselves been instrumental in raising awareness of the political and historical dimensions of past efforts to care for and control those previously labelled 'idiotic'.

Dominated by historians of medicine, recent literature on idiocy, imbecility and feeble-mindedness has focused predominantly on medical and legislative approaches and has not pursued broader cultural representations of mental deficiency in sufficient depth. Martin Halliwell's Images of Idiocy attempts to redress that imbalance by focusing almost exclusively, and with great originality, on the treatment of 'idiots' in both fiction and films throughout the nineteenth and twentieth centuries. After a temperate introduction setting out the methodological framework for reading literary and cinematic images and a brief outline of the longer history of idiocy from the cognitive aspirations of the Enlightenment to the romantic visions of the Victorian period, the book proceeds to tackle the representation and meaning of idiot figures in a range of literature, from Flaubert's Charles Bovary through Dostoevsky's Myshkin to Rohinton Mistry's Tehmul. In each case, close analysis of the literary texts is complemented by careful discussion of the gaps between literary images and subsequent film adaptations.

There are perhaps two central theses running through Images of Idiocy, 
both of which carry fruitful insights for historians of psychiatry. In the first place, Halliwell demonstrates how notions and images of idiocy were routinely over-determined by broad political and socio-cultural anxieties. Even ostensibly objective medical and scientific definitions of idiocy were framed and informed by trenchant concerns about the maintenance of political and social order and about preserving the boundaries of modern civilization. Of course, this contention is familiar to historians of medicine, particularly those committed to some form of social constructionism, but it is useful to have it reconfigured through a set of sources completely different from those usually utilized by medical historians. Secondly, Halliwell suggests that novelists and film-makers have often adopted the idiot figure as a potent means of exploring a range of alternative questions about, for example, contemporary notions of normality, morality, criminality, alienation and exile. This strand of Halliwell's narrative offers substantially new insights into historical constructions of idiocy.

Not surprisingly, given his professional allegiance to English and American studies and his previous publications, Halliwell is more assured in his analysis of literary and cinematic representations of idiocy than he is in his discussion of the parallel medical and legislative history of mental deficiency. Indeed, at times the book would have benefited from a closer engagement with recent historical literature on both sides of the Atlantic which does cover cognate developments in medical and cultural perceptions of idiocy; this would have added greater depth and context to Halliwell's study. Thus, there is no mention of recent monographs by Mathew Thomson (1998) and David Wright (2001) on England, of research by Steven Noll (1995), James W. Trent (1994) and Nicole Hahn Rafter on America, or, dare I mention it, of my own work on the permeable and elastic boundaries of imbecility and feeble-mindedness (Jackson, 2000). The result is that, while Halliwell undoubtedly offers a colourful account of the changing role of idiots in fiction and film from romanticism through modernism to the post-modern period, it is not always clear how literary representations engaged with, drew upon and informed medical and educational images and policies. Thus, the opportunity for a truly interdisciplinary study of idiocy is lost.

Notwithstanding this criticism, Halliwell has successfully and creatively opened up new territories in the history of mental deficiency. In doing so, he has exposed the value of exploring a far wider sets of sources than those routinely employed by many historians and has generated the intellectual space in which to promote future dialogue between medical and cultural historians.

MARK JACKSON

Centre for Medical History University of Exeter 


\section{References}

Jackson, Mark (2000) The Borderland of Imbecility (Manchester: Manchester University Press). Noll, Steven (1995) Feeble-minded in Our Midst (Chapel Hill: University of North Carolina Press).

Thomson, Mathew (1998) The Problem of Mental Deficiency (Oxford: Clarendon Press).

Trent, James W. (1994) Inventing the Feeble Mind (Berkeley: University of California Press).

Wright, David (2001) Mental Disability in Victorian England: The Earlswood Asylum 1847-1901 (Oxford: Clarendon Press). 